REGARDS

SUR L'ECONOMIE ALLEMANDE

BULLETIN ECONOMIQUE DU CRAC

\section{Regards sur l'économie allemande}

Bulletin économique du CIRAC

$68 \mid 2004$

Varia

\title{
Entreprise sociale
}

SCHÄFER Henry, LINDENMAYER Philipp, Sozialkriterien im Nachhaltigkeitsrating

\section{(2) OpenEdition}

Journals

Édition électronique

URL : http://journals.openedition.org/rea/3641

DOI : $10.4000 /$ rea.3641

ISBN : 978-2-8218-0832-4

ISSN : $1965-0787$

Éditeur

CIRAC

Édition imprimée

Date de publication : 1 octobre 2004

ISSN : 1156-8992

Référence électronique

«Entreprise sociale », Regards sur l'économie allemande [En ligne], 68 | octobre 2004, mis en ligne le 29 avril 2009, consulté le 22 septembre 2020. URL : http://journals.openedition.org/rea/3641 ; DOI : https://doi.org/10.4000/rea.3641

Ce document a été généré automatiquement le 22 septembre 2020

(C) CIRAC 


\section{Entreprise sociale}

SCHÄFER Henry, LINDENMAYER Philipp, Sozialkriterien im Nachhaltigkeitsrating

\section{RÉFÉRENCE}

SCHÄFER Henry, LINDENMAYER Philipp, Sozialkriterien im Nachhaltigkeitsrating, Edition der Hans Böckler Stiftung, vol. 104, Düsseldorf, 2004, 150 p.

1 Qu'est-ce qu'une entreprise sociale, vouée au développement durable ? Cette question intéresse aussi outre-Rhin, peut-être même plus qu'en France, la notion de développement durable y ayant une longue tradition, notamment dans le secteur financier. Or dans le cadre du développement de critères de performance et de solvabilité (ratings) en cours d'adoption («Bâle II »), la question est fondamentale. Etat des lieux des pratiques du rating social en Allemagne. (ib) 